\title{
BIOLOGICAL ACTIVITIES OF ALTERNARIA SP. RL4 - A POTENT ENDOPHYTIC FUNGUS ASSOCIATED WITH RAUVOLFIA SERPENTINA L. BENTH.
}

\author{
RANJAN GHOSH ${ }^{1}$, SOMA BARMAN ${ }^{2}$, PAVAN KUMAR JGS ${ }^{3}$, NARAYAN C MANDAL ${ }^{1 *}$
}

${ }^{1}$ Mycology and Plant Pathology Laboratory, Department of Botany, Visva-Bharati, Santiniketan - 731 235, West Bengal, India. ${ }^{2}$ Soil and Agrobio-engineering Laboratory, Department of Environmental Science, Tezpur University, Napaam, Tezpur - 784 028, Assam, India. ${ }^{3}$ School of Bioscience and Technology, Vellore Institute of Technology, Chennai - 600 127, India.

Received: 24 May 2018, Revised and Accepted: 04 July 2018

ABSTRACT

Objectives: Endophytic fungi are considered as an important source of bioactive metabolites. The present study focused on the isolation of potent endophytic fungal strains from well-known medicinal plant Rauvolfia serpentina L. Benth. having biological activities.

Materials \& Methods: Fungal endophytes were isolated from aerial parts of the plant and the potent strain was selected on the basis of antibacterial activities of cell-free supernatant (CFS). Ethyl acetate (EA) extraction of CFS was done and mode of action of EA fraction was checked against pathogenic bacteria. EA fraction was also analyzed by thin-layer chromatography (TLC). In addition, antioxidant activity was checked by 1,1-Diphenyl2-picrylhydrazyl-free radical scavenging assay and anticancer activity was checked against breast cancer cell line MCF-7 by MTT assay.

Results: Among the different endophytic fungal isolates, CFS of Alternaria sp. RL4 produced prominent zones of inhibition against numbers of Gram-positive pathogenic bacteria including Staphylococcus aureus $(12 \pm 0.5 \mathrm{~mm})$ and Listeria monocytogenes (17 $\pm 2.0 \mathrm{~mm})$. Massive reductions in bacterial CFS were noticed upon treatment with EA fraction $(2 \mathrm{mg} / \mathrm{ml})$. It also showed strong cidal mode of action against Gram-positive organisms. TLC analysis revealed the production of two different compounds with antibacterial potentials. In addition, EA fraction of RL4 showed very good antioxidant property with an $\mathrm{IC}_{50}$ value of $49.80 \pm 2.11 \mu \mathrm{g} / \mathrm{ml}$. MTT assay also suggested the anticancerous properties of EA fraction of RL4.

Conclusion: Alternaria sp. RL4 could be a very good source of bioactive compounds for the development of new drugs.

Keywords: Rauvolfia serpentina, Endophytic fungi, Antimicrobial potential, Cidal mode of action, Antioxidant activity, Anticancerous activity.

(C) 2018 The Authors. Published by Innovare Academic Sciences Pvt Ltd. This is an open access article under the CC BY license (http://creativecommons. org/licenses/by/4. 0/) DOI: http://dx.doi.org/10.22159/ajpcr.2018.v11i11.27500

\section{INTRODUCTION}

Symbiotic relationship between plants and microorganisms is considered as one of the important factors for colonization of plants on the land. Among different types of microbial symbionts, endophytic fungi which live inside the plant tissues without producing any sign of existence play an important role in defense and plant growth promotion [1]. They take nutrition from the plant to survive in different biotic and abiotic stress conditions [2,3] and produce several bioactive compounds to protect the host plant. Endophytic fungi reported from various groups of plant are good sources of secondary metabolites and could serve as vectors for the introduction of genes that can confer pest resistance and for the expression of important traits [4,5]. Natural products from fungal endophytes have broad spectrum of biological activities, and these metabolites encompass a diverse range of structures including alkaloids, steroids, terpenoids, phenylpropanoids, quinines, peptides, and xanthones [6]. Among the different bioactive secondary metabolites produced by microorganisms, $38 \%$ are of fungal origin [7]. Taxol, a potent anticancerous drug, produced by the endophytic fungus Taxomyces andreanae was discovered from Taxus brevifolia [4].

Rauvolfia serpentina L. Benth. (family - Apocynaceae), commonly known as "Indian snakeroot" or "sarpagandha," is a species of flowering plant with useful medicinal values. It is native to the Indian subcontinent and East Asia (from India to Indonesia). $R$. serpentina contains a number of bioactive chemicals, including yohimbine, reserpine, ajmaline, deserpidine, rescinnamine, and serpentinine. $R$. serpentina is widely used medicinally both in modern medicinal system and also in ayurvedic, unani, and folk medicine. Nath et al. [8] have characterized Colletotrichum gloeosporioides, Penicillium sp., and Aspergillus awamori as fungal endophytes from $R$. serpentina with hypocholesterolemic, antimicrobial, and antioxidant potential.

The types of endophytes within the same plant varies with different habitats, different parts of the plant as well as in different seasonal conditions [9]. In the present endeavor, we have tried to isolate and characterize endophytic fungi from $R$. serpentina collected from the lateritic soil of Santiniketan, West Bengal. The antimicrobial potential, antioxidant activity, and anticancerous property of the potent isolate were also studied during this period.

\section{METHODS}

\section{Collection of plant materials}

Healthy and mature $R$. serpentina plants were randomly collected from the lateritic soil of Santiniketan, West Bengal, India. The plant materials were brought to the laboratory in sterilized polythene bags. Fresh plant materials were selected for the isolation of endophytic fungi.

\section{Isolation and purification of endophytic fungi}

Collected plant materials were washed in running tap water and stem as well as leaf samples were cut into small pieces. Leaves were cut into 3-4 $\mathrm{mm}$ in diameter and $0.5-1 \mathrm{~cm}$ in length without midrib and stem were cut into $0.5-1 \mathrm{~cm}$ in length. Plant materials were then surface sterilized with $4 \%$ sodium hypochlorite and finally washed for three times with sterilized distilled water. The sterilized stem and leaf samples were placed on potato dextrose agar (PDA) plates incorporated with streptomycin $(100 \mu \mathrm{g} / \mathrm{ml})$ to prevent bacterial contamination and incubated at $28^{\circ} \mathrm{C}$ for 3-4 days. After the emergence of fungal mycelia, they were purified by streaking and stored in PDA slants for further studies. 
Characterization and identification of isolated fungi

The isolated fungal strains were characterized and identified by light microscopic studies [10]. A little amount of fungal mycelia was taken on a clean glass slide and stained with cotton blue. Excess stain was removed and mounted with a cover glass using lactophenol. The specimens were observed under light microscope (Olympus CH2Oi) and identified on the basis of their morphological characteristics.

\section{Antimicrobial screening of isolated endophytes}

To select the isolated endophytes with antimicrobial potentials, all of the isolated strains were grown in $100 \mathrm{ml}$ of potato dextrose broth at $28^{\circ} \mathrm{C}$ for 7 days. The cell-free supernatants (CFS) were taken after filtration with Whatman No. 1 filter paper followed by centrifugation at $6000 \mathrm{rpm}$ for $10 \mathrm{~min}$ and antimicrobial activities were checked by agar well diffusion method [11]. $50 \mu$ CFS was added to the wells of agar plates. Zones of inhibition were observed and diameters were measured. Antimicrobial potentials of isolated endophytes were studied against a number of Gram-positive and Gram-negative pathogenic bacteria.

\section{Extraction of culture filtrates of endophytic fungus}

After initial screening, one of the potent fungal strains RL4 isolated from Rauvolfia leaf was inoculated in $1 \mathrm{~L}$ of potato dextrose broth and incubated at $28^{\circ} \mathrm{C}$ for 10 days. CFS was taken after filtration followed by centrifugation at $6000 \mathrm{rpm}$ for $10 \mathrm{~min}$ and extracted with ethyl acetate (EA). $40 \mathrm{ml}$ of EA was added for every $100 \mathrm{ml}$ of culture filtrate, mixed vigorously and the EA layer was separated using separating funnel. The EA extract was then evaporated to dryness in vacuum evaporator at room temperature $\left(26 \pm 2^{\circ} \mathrm{C}\right)$, weighed and stored at $4^{\circ} \mathrm{C}$ for further studies.

\section{Antibacterial study}

Antibacterial activity of EA fraction of CFS of RL4 was checked against three Gram-positive bacteria, namely Bacillus subtilis MTCC121, Staphylococcus aureus MTCC96, and Listeria monocytogenes MTCC657 by disc diffusion method [12]. Different concentrations $(1-10 \mathrm{mg} / \mathrm{ml})$ of EA fractions were prepared after dissolving in dimethyl sulfoxide (DMSO), sterilized paper discs (Whatman No. 1) were soaked and placed on the lawn of pathogenic bacteria in nutrient agar (NA) plates. Plates were incubated for $24 \mathrm{~h}$ at their respective growth temperatures. Zones of inhibition were observed and diameters were measured.

Antibacterial activity of the EA fraction was also checked by counting the colony-forming units (CFUs) against these Gram-positive bacteria. $1 \%$ of bacterial culture (OD at $620 \mathrm{~nm}=0.5$ ) was added to fresh nutrient broth and treated with EA fraction at a concentration of $2 \mathrm{mg} / \mathrm{ml}$. After $24 \mathrm{~h}$ of incubation at their respective growth temperatures, CFUs were counted by spreading on NA plates and compared with untreated control.

To determine the mode of action, the EA fraction was added on actively growing cultures of three Gram-positive bacteria mentioned earlier at a concentration of $2 \mathrm{mg} / \mathrm{ml}$ followed by counting the CFUs at different time intervals and plotting the values in graphs [13].

\section{Thin-layer chromatographic (TLC) analysis}

The EA fraction of the CFS of the endophytic fungus was analyzed by TLC. The dried fraction was redissolved in EA at a concentration of $20 \mathrm{mg} / \mathrm{ml}$ and $10 \mu \mathrm{l}$ of suspension was spotted on TLC plates (MERCK Silica gel $\mathrm{F}_{255}$ ). EA and chloroform in the ratio 1:1 were used as running solvent. Retention factor (Rf) values for all the bands were calculated under ultraviolet light. The bands were then cut and placed on lawn of bacteria on NA plates to check the antibacterial activities. Zones of inhibition were observed after $24 \mathrm{~h}$ of incubation.

\section{Antioxidant activity}

Free radical scavenging activity of EA fraction was determined using 1,1-Diphenyl-2-picrylhydrazyl (DPPH) by the method described by Lee et al. [14]. The dried EA fraction was dissolved in methanol at a concentration of $10 \mathrm{mg} / \mathrm{ml} .100 \mu \mathrm{l}$ of various concentrations of the methanolic fractions were mixed with $2900 \mu \mathrm{l}$ DPPH solution and incubated in the dark at room temperature for $30 \mathrm{~min}$. In control set, only $100 \mu \mathrm{l}$ of methanol was added to the DPPH. The absorbance was recorded at $517 \mathrm{~nm}$. The percentage of free radical scavenging activity of methanolic extract was calculated as: $\% \mathrm{I}=\left[\left(\mathrm{A}_{\text {blank }}-\mathrm{A}_{\text {sample }}\right) / \mathrm{A}_{\text {blank }}\right] \times 100$. Where $A_{\text {blank }}$ : Absorbance of control; $A_{\text {sample }}$ : Absorbance of methanolic extract and DPPH. IC ${ }_{50}$ was calculated by plotting straight line equation.

\section{Anticancerous activity}

The anticancerous study was carried out using human breast cancer cell line MCF7. $1 \times 10^{4}$ cells were seeded into each well in 96 well plates and allowed to stand for $24 \mathrm{~h}$. After $24 \mathrm{~h}$, complete media was removed

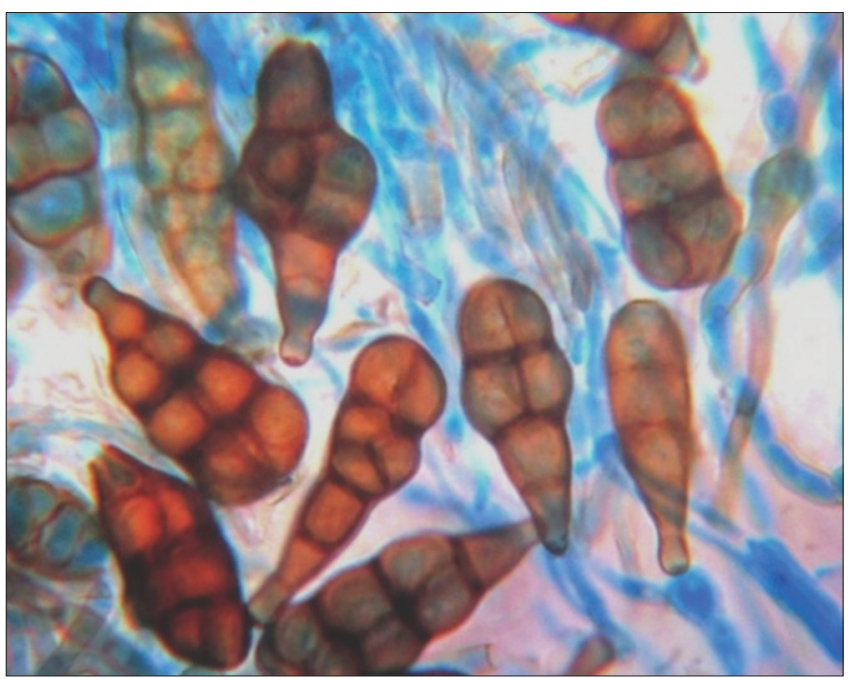

Fig. 1: Alternaria sp. RL4 under light microscope

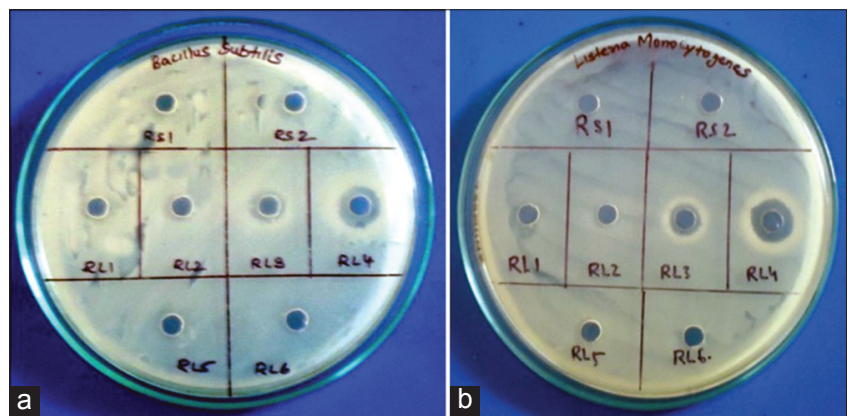

Fig. 2: Zone of inhibition produced by cell-free supernatant of the endophytic fungi against Gram-positive bacteria: (a) B. subtilis MTCC121, (b) L. monocytogenes MTCC657

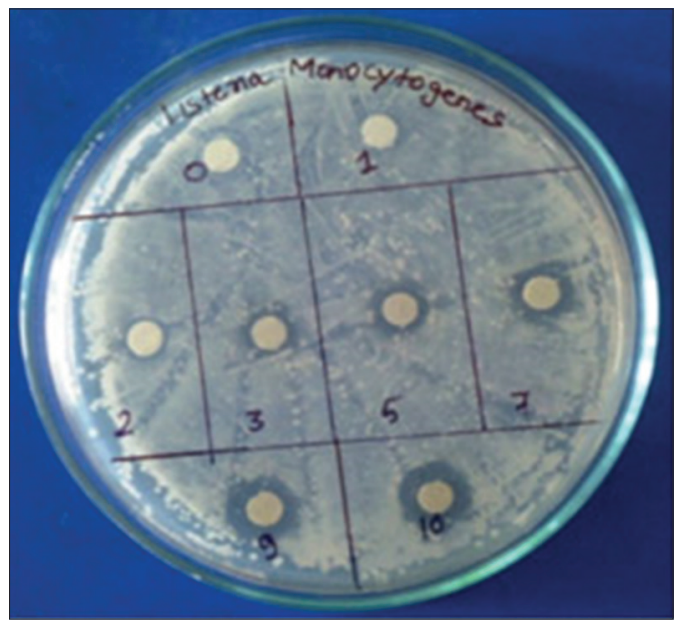

Fig. 3: Zones of inhibition produced by different concentration of ethyl acetate fraction of RL4 against L. monocytogenes MTCC657 


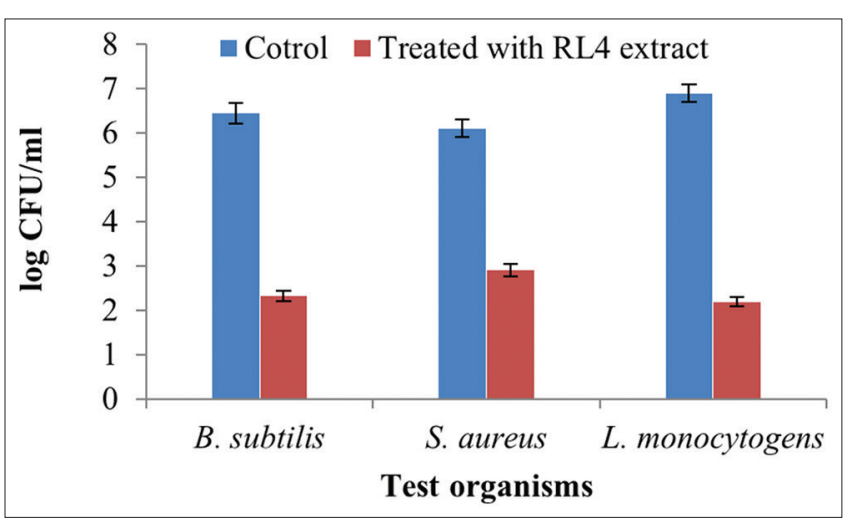

Fig. 4: Effects of ethyl acetate fraction $(2 \mathrm{mg} / \mathrm{ml})$ of RL4 on colonyforming units of pathogenic bacteria

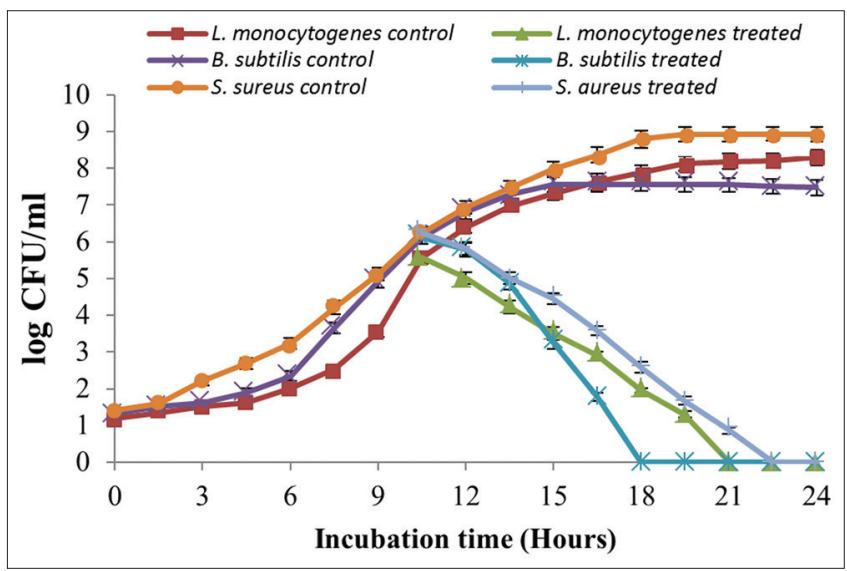

Fig. 5: Cidal activity of ethyl acetate fraction $(2 \mathrm{mg} / \mathrm{ml})$ of RL4 on pathogenic bacteria

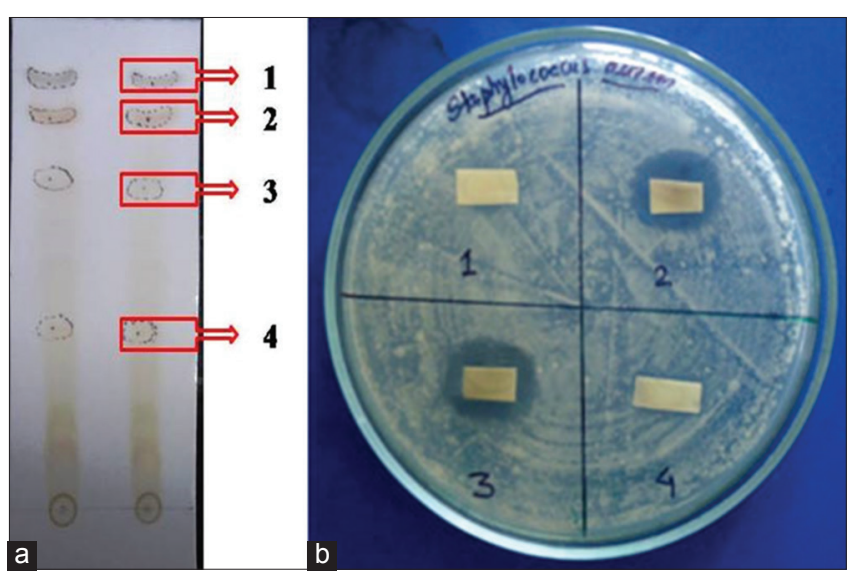

Fig. 6: Antimicrobial activity of ethyl acetate fraction RL4 against S. aureus MTCC96 after TLC analysis: (a) separation on TLC plate,

(b) zones of inhibition produced by different bands

and the wells were replenished with incomplete media (without FBS) and different concentrations $(1,5,10,50$, and $100 \mu \mathrm{g} / \mathrm{ml})$ of the crude extract of the endophytic fungus Alternaria sp. Some wells were kept untreated as control. Plates were incubated for $24 \mathrm{~h}$ at $37^{\circ} \mathrm{C}$ in a $5 \%$ $\mathrm{CO}_{2}$ incubator (Thermo Scientific, USA) and after the incubation period, proliferation was estimated by MTT assay method at $595 \mathrm{~nm}$ [15]. All experiments were performed and recorded as cell viability percentage in comparison with the control experiment. Cell death percentage was calculated considering $0 \%$ death in control experiments. $50 \mathrm{mM}$ Mytomycin C was used as positive control.

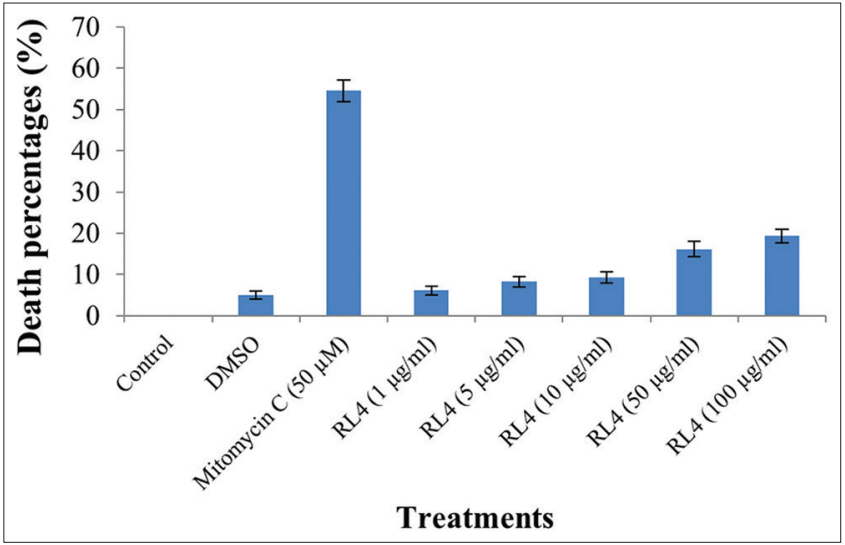

Fig. 7: MTT assay result of MCF7 after treatment with the crude extracts of RL4

Table 1: Zones of inhibition produced by endophytic fungal strains against pathogenic organisms

\begin{tabular}{lll}
\hline Pathogenic organisms & \multicolumn{2}{c}{ Diameter of inhibition zones (mm) } \\
\cline { 2 - 3 } & RL3 (Alternaria sp.) & RL4 (Alternaria sp.) \\
\hline B. subtilis MTCC121 & $8 \pm 1.0$ & $10 \pm 2.0$ \\
L. monocytogenes & $6 \pm 1.5$ & $17 \pm 1.0$ \\
MTCC657 & & \\
S. aureus MTCC96 & $6 \pm 1.0$ & $12 \pm 0.5$ \\
P. aeruginosa MTCC741 & - & - \\
E. coli MTCC1667 & - & - \\
S. typhimurium MTCC98 & - & - \\
\hline
\end{tabular}

B. subtilis: Bacillus subtilis, L. monocytogenes: Listeria monocytogenes, S. aureus: Staphylococcus aureus, P. aeruginosa: Pseudomonas aeruginosa, E. coli: Escherichia coli, S. typhimurium: Salmonella typhimurium

\section{Statistical analysis}

Each data represented is average of at least three replicates. Means and standard deviations were calculated using Microsoft Excel 2007 program.

\section{RESULTS}

Endophytic fungi were isolated from disease-free, healthy leaves and stems of $R$. serpentina plants. A total of eight different fungal strains were isolated from 30 leaves and 20 stem segments. During morphological characterization under light microscope, two isolatess were identified as Colletotrichum spp., four were identified as Alternaria spp., and remaining two were unidentified due to the absence of reproductive structures.

Among the eight different isolates, CFS of two fungal strain, namely RL3 and RL4, which were isolated from leaves of R. serpentina and identified as species of Alternaria (Fig. 1), showed prominent zones of inhibition (Table 1) against all of the Gram-positive bacterial strains (Fig 2), namely B. subtilis $(10 \pm 2.0 \mathrm{~mm})$, S. aureus $(12 \pm 0.5 \mathrm{~mm})$, and L. monocytogenes $(17 \pm 1.0 \mathrm{~mm})$. No inhibition zone was found against any of the Gram-negative bacteria tested. Among these two strains, RL4 was more effective than RL3 to produce zones of inhibitions against pathogenic bacteria.

On the basis of antimicrobial potential, the isolated fungal strain Alternaria sp. RL4 was selected for EA extraction of antimicrobial principles. When the antimicrobial potential of the EA fraction was checked by disc diffusion method, it was found that the EA fraction was able to produce zones of inhibition against all of the tested bacteria, namely B. subtilis, L. monocytogenes, and S. aureus at a concentration of $2 \mathrm{mg} / \mathrm{ml}$ (Fig. 3). It was also observed that the extract showed maximum zones of inhibition against $L$. monocytogenes which is a foodborne pathogen causing spoilage of different food products (Table 2). 
Table 2: Diameter of inhibition zones produced by different concentration of EA fraction of RL4 against pathogenic bacteria

\begin{tabular}{|c|c|c|c|}
\hline \multirow{2}{*}{$\begin{array}{l}\text { Concentrations of EA } \\
\text { fraction }(\mathrm{mg} / \mathrm{ml})\end{array}$} & \multicolumn{3}{|c|}{ Diamter of inhibition zones $(\mathrm{mm})$ against pathogenic bacteria } \\
\hline & B. subtilis MTCC121 & L. monocytogenes MTCC657 & S. aureus MTCC96 \\
\hline 1 & 0 & 0 & 0 \\
\hline 2 & $6 \pm 1.0$ & $8 \pm 1.5$ & $6 \pm 1.0$ \\
\hline 3 & $7 \pm 2.0$ & $9 \pm 1.0$ & $6 \pm 1.0$ \\
\hline 5 & $8 \pm 1.5$ & $10 \pm 1.0$ & $7 \pm 1.5$ \\
\hline 7 & $9 \pm 1.5$ & $10 \pm 1.5$ & $8 \pm 1.5$ \\
\hline 9 & $10 \pm 2.0$ & $12 \pm 2.5$ & $8 \pm 2.0$ \\
\hline 10 & $10 \pm 2.0$ & $12 \pm 2.0$ & $9 \pm 2.0$ \\
\hline
\end{tabular}

EA: Ethyl acetate

Table 3: Percentage of inhibition of free radicals by crude extract of RL4

\begin{tabular}{ll}
\hline $\begin{array}{l}\text { Concentration of crude } \\
\text { extract }(\mu \mathbf{g} / \mathbf{m l})\end{array}$ & $\begin{array}{l}\text { Percentage }(\%) \text { of } \\
\text { inhibition of free radicals }\end{array}$ \\
\hline 0 & 0 \\
10 & $9.34 \pm 1.68$ \\
20 & $18.26 \pm 1.97$ \\
30 & $28.3 \pm 2.71$ \\
50 & $50.20 \pm 2.13$ \\
75 & $79.8 \pm 3.2$ \\
100 & $98.5 \pm 2.43$ \\
IC50 & $49.80 \pm 2.11 \mu \mathrm{g} / \mathrm{ml}$ \\
\hline
\end{tabular}

Antimicrobial activity of the EA fraction of RL4 was also checked against three Gram-positive bacteria by counting the CFUs. 64.04\%, $52.38 \%$, and $68.12 \%$ inhibition in the number of the CFUs were noticed in case of B. subtilis, S. aureus, and L. monocytogenes, respectively, in the presence of $2 \mathrm{mg} / \mathrm{ml}$ of the crude EA fraction (Fig. 4)

To study the mode of action of the antimicrobial principle, the EA fraction of RL4 was added to the mid-log phase culture of B. subtilis, S. aureus, and L. monocytogenes. After addition of the extract, a rapid decrease in the number of CFUs were noticed for all of the bacteria (Fig. 5).

TLC analysis of EA fraction of CFS of RL4 revealed four distinct bands with Rf values of $0.864 \pm 0.032,0.790 \pm 0.024,0.641 \pm 0.019$, and $0.345 \pm 0.027$ under UV light. When the antimicrobial properties of individual bands were studied, band $2(\mathrm{Rf}=0.790 \pm 0.024)$ and band 3 $(\mathrm{Rf}=0.641 \pm 0.019)$ were able to produce prominent zones of inhibition against all of the three Gram-positive bacteria (Fig. 6).

A prominent color changes from pink to yellow during DPPH freeradical scavenging assay in the presence of different concentration of the crude extract of RL4 also suggested very good antioxidant property. When optical densities were measured and percentages of inhibition were calculated, $98.5 \pm 2.43 \%$ inhibition of free radicals was noticed at a concentration of $100 \mu \mathrm{g} / \mathrm{ml}$ of crude extract (Table 3). From the standard curve of percentage $(\%)$ of inhibitions, $\mathrm{IC}_{50}$ value of crude extract of RL4 was calculated as $49.80 \pm 2.11 \mu \mathrm{g} / \mathrm{ml}$. Ascorbic acid, which was used as positive control, showed an IC50 value of $20.23 \mu \mathrm{g} / \mathrm{ml}$.

Anticancerous activity of EA extract of RL4 was studied at different concentrations (dissolved in DMSO) against human breast cancer cell line MCF7. Death percentages of cells were found to be $16.13 \pm 1.84 \%$ and $19.36 \pm 1.66 \%$ in the presence of $50 \mu \mathrm{g} / \mathrm{ml}$ and $100 \mu \mathrm{g} / \mathrm{ml}$ crude extract, respectively (Fig. 7). $54.56 \pm 2.61 \%$ cell death was found in the presence $50 \mathrm{mM}$ Mitomycin $\mathrm{C}$ used as positive control.

\section{DISCUSSIONS}

In the present study, eight endophytic fungi were isolated from $R$. serpentina mostly belonging to the genus Alternaria and Colletotrichum. Nath et al. [8] reported the presence of Colletotrichum,
Penicillum, and Aspergillus as endophytes in $R$. serpentina whereas Qadri et al. [16] reported the presence of only Alternaria spp. Among the different isolates CFS of two strains, namely RL4 and RL3, identified as Alternaria spp. were able to inhibit Gram-positive bacteria in vitro. As RL4 was more effective than RL3, it was taken for further studies. The EA fraction of the CFS of RL4 showed prominent zones of inhibition against Gram-positive bacteria, namely B. subtilis, $S$. aureus, and L. monocytogenes, but it was unable to inhibit Gram-negative bacteria. Most of the bioactive metabolites from endophytic fungi reported were more effective against Gram-positive bacteria than Gram-negative bacteria and pathogenic fungi [17]. The reason for the sensitivity of the extract only against Gram-positive bacteria may be due to the differences between cell wall composition with that of Gram-negative microorganisms. In Gram-negative bacteria, the outer wall layer is made up of lipopolysaccharide. This makes the cell wall impermeable to lipophilic solutes. Gram-positive bacteria are more susceptible due to the presence of only an outer peptidoglycan layer which is not an effective permeability barrier [18,19]. Hellwig et al. [20] reported a novel antibacterial antibiotic altersetin from endophytic Alternaria sp. which was effective against Gram-positive bacteria. During mode of action studies, a rapid decrease in the numbers of CFUs indicated strong cidal nature of the antimicrobial principles. Production of prominent zones of inhibition by band 2 and band 3 after TLC analysis against all of the Gram-positive bacteria tested, suggested that Alternaria sp. RL4 was able to produce at least two different compounds with antimicrobial activities. Antioxidant compounds play an important role as a health-protecting factor. Scientific evidence suggests that antioxidants reduce the risk for chronic diseases including cancer and heart disease [21]. Crude extract of Alternaria sp. RL4 was also showed very good antioxidant activities. Antioxidant activities by different endophytes have also been reported by several workers [22-24]. Death of human breast cancer cell MCF7 after treatment with crude extract of RL4 strongly suggested anticancerous property of the extract. Large numbers of secondary metabolites with potent anticancerous activities have already been isolated from endophytic fungi [25-27]. Therefore, secondary metabolites produced by endophytic fungi could be alternative sources for development of novel anticancer drugs [28,29].

\section{CONCLUSIONS}

Endophytic fungi Alternaria sp. RL4 isolated from R. serpentina showed very good antibacterial activities against Gram-positive pathogenic bacterial strains. It can produce at least two different antibacterial compounds with cidal mode of action. In addition, it also showed antioxidant and anticancerous properties. Therefore, Alternaria sp. RL4 could be a very good source of bioactive compounds or in development of new drugs.

\section{ACKNOWLEDGMENTS}

We are thankful to DST INSPIRE Program and Indian Academy of Sciences for financial support. We are also thankful to Dr. Anshuman Chatterjee, Department of Zoology, Visva-Bharati for his help during the anticancerous study. 


\section{AUTHOR'S CONTRIBUTION}

R. Ghosh, S. Barman, and Pavan Kumar J G S performed mainly the experimental parts of the work. R. Ghosh written the MS. N.C. Mandal supervised the overall work and also corrected the MS

\section{CONFLICT OF INTEREST}

The authors declare no conflict of interest.

\section{REFERENCES}

1. Petrini O. In: Andrews JH, Hiran SS, editors. Microbial Ecology of Leaves. New York: Springer Verlag; 1991.

2. Kharwar RN, Verma VC, Strobel G, Ezra D. The endophytic fungal complex of Catharanthus roseus (L) G. Don. Curr Sci 2008;95:228-33.

3. Gond SK, Verma VC, Mishra A, Kumar A, Kharwar RN. Role of fungal endophytes in plant protection. In: Arya A, Perello AE, editors. Management of Fungal Plant Pathogens. Wallingford: CAB International; 2010. p. 183-97.

4. Stierle A, Strobel G, Stierle D. Taxol and taxanae production by Taxomyces ndreanae and endophytic fungus of Pacific Yew. Sciences 1993;260:214-6.

5. Strobel GA, Daisy B. Bio processing for microbial endophytes and their natural products. Microbiol Mol Biol Rev 2003;67:491-502.

6. Zhang HW, Song YC, Tan RX. Biology and chemistry of endophytes. Nat Prod Rep 2006;23:753-71.

7. Berdy J. Bioactive microbial metabolites-a personal view. J Antibiot 2005;58:1-26

8. Nath A, Chattopadhyay A, Joshi SR. Biological Activity of endophytic fungi of Rauwolfia serpentina Benth: An ethnomedicinal plant used in folk medicines in Northeast India. Proceedings of the national academy of sciences, India section B. Biol Sci 2015;85:233-40.

9. Fang W, Yang L, Zhu X, Zeng L, Xinghui L. seasonal and habitat dependent variations in culturable endophytes of Camellia sinensis. J Plant Pathol Microb 2013;4:3.

10. Ghosh R, Barman S, Khatun J. Mandal NC biological control of Alternaria alternata causing leaf spot disease of Aloe vera using two strains of Rhizobacteria. Biol Control 2016;97:102-8.

11. Fernández-Garayzábal JF, Delgado C, Blanco M, Vázquez-Boland JA, Briones $\mathrm{V}$, et al. Role of potassium tellurite and brain heart infusion in expression of the hemolytic phenotype of Listeria spp. on agar plates. Appl Environ Microbiol 1992;58:434-8.

12. Bauer AW, Kirby WM, Sherris JC, Turck M. Antibiotic susceptibility testing by a standardized single disk method. Am J Clin Pathol 1966;45:493-6.

13. Barman S, GhoshR, Mandal NC. Use ofBacteriocin producing Lactococcus lactis subsp. lactis LABW4 to prevent Listeria monocytogenes induced spoilage of meat. Food Nutr Sci 2014;5:2115-23.

14. Lee SK, Mbwambo ZH, Chung H, Luyengi L, Gamez EJ, Mehta RG, et al. Evaluation of the antioxidant potential of natural products. Comb Chem High Throughput Screen 1998;1:35-46

15. Mosmann T. Rapid colorimetric assay for cellular growth and survival: Application to proliferation and cytotoxicity assays. J Immunol Methods 1983;16:55-63.

16. Qadri M, Johri S, Shah, BA, Khajuria A, Sidiq T, Lattoo SK, et al. Identification and bioactive potential of endophytic fungi isolated from selected plants of the Western Himalayas. Springer Plus 2013;2:8.

17. Chareprasert S, Piapukiew J, Thienhirun S, Whalley A, Sihanonth P. Endophytic fungi of teak leaves Tectona grandis L. and rain tree leaves Samanea saman Merr. World J Microbiol Biotechnol 2006;22:481-6.

18. Pandey B, Ghimire P, Agrawal VP. Studies on the anti-bacterial activity of the actinomycetes isolated from the Khumbu region of Nepal. J Biol Sci 2004;23:44-53.

19. Ogundare AO, Adetuyi FC, Akinyosoye FA. Antimicrobial activities of Vernonia tenoreana. Afr J Biotechnol 2006;5:1663-8.

20. Hellwig V, Grothe T, Mayer-Bartschmid A, Endermann R, Geschke FU, Henkel T, et al. Altersetin, a new antibiotic from cultures of endophytic Alternaria spp. Taxonomy, fermentation, isolation, structure elucidation and biological activities. J Antibiot (Tokyo) 2002;10:881-92.

21. Willcox JK, Ash SL, Catignani GL. Antioxidants and prevention of chronic disease. Crit Rev Food Sci Nutr 2004;44:275-95.

22. Muharni E, Rizki M. Isolation of antioxidant compound from endophytic fungi Acremonium sp. From the Twigs of Kandis Gajah. Makara J Sci 2012;16:46-50

23. Gurupavithra S, Jayachitra A. Isolation and identification of endophytic fungi from Ocimum sanctum and analyse its antioxidant properties. Int J Res Pharm Biomed Sci 2013:4:1120-5.

24. Chowdhury DR, Chattopadhyay SK, Roy SK. Assessment of secondary metabolites with relation to their antioxidant activity of fungal endophytes isolated from medicinal plants. Int J Pharm Pharm Sci 2018;10:59-63.

25. Tan RX, Zou WH. Endophytes: A rich source of functional metabolites. Nat Prod Rep 2001;18:448-59.

26. Chanda S. Endophytic fungi: Novel source of anticancer lead molecules. Appl Microbiol Biotechnol 2012;95:47-59.

27. Prabavathy D, Nachiyar CV. Antimicrobial and antidiabetic activity of an endophytic fungi isolated from Adhatoda beddomei. Int $\mathrm{J}$ Pharm Pharm Sci 2013;5:780-3.

28. Guo B, Wang Y, Sun X, Tang K. Bioactive natural products from endophytes: A review. Appl Biochem Microbiol 2008;44:136-42.

29. Selim KA, EL-beih AA, AbdEl-Ranman TM, EL-Diwany AI. Biology of endophytic fungi. Curr Res Environ Appl Mycol 2012;2:31-82. 